
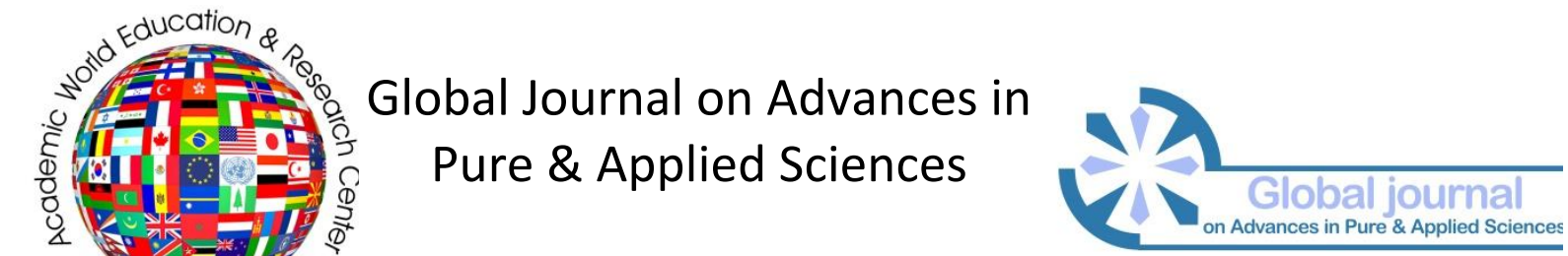

Issue 7 (2016) 48-56

Selected Paper of 2nd World Conference on Health Sciences (H-SCl 2015)

30 April-02 May 2015Efes Surmeli Hotel \& Convention Center - Izmir, Kusadası, Turkey

\title{
The effect of informing mothers on level of anxiety in day surgery of children
}

Aysun Yılmaz ${ }^{*}$, Eskisehir School of Health, Eskisehir Osmangazi University, Eskisehir,Turkey. Mevlit Korkmaz,Medical Faculty Hospital, The Department of Pediatric Surgery, Fatih University, Istanbul,Turkey.

\section{Suggested Citation:}

Yılmaz, A. \&Korkmaz, M.(2016). The effect of informing mothers on level of anxiety in day surgery of children,Global Journal on Advances in Pure \& Applied Sciences. [Online]. 07, pp 48-56. Available from: www.propaas.eu

Received November 11, 2014; revised December 16, 2014; accepted March 10, 2015.

Selection and peer review under responsibility ofProf. Dr. Fahrettin Sadıkoglu, Near East University.

(C)2016Academic World Education \& Research Center. All rights reserved.

\begin{abstract}
Objective:The aim of the study is to examine the effect of informing mothers before operations on the level of anxiety in day surgeries of children.Materials and Methods: The study was an intervention type and was carried out in the departments of otolaryngology and pediatric surgery in Eskisehir Osmangazi University Medical Faculty Hospital and in the department of pediatric surgery in Afyon Kocatepe University Medical Faculty Hospital. A total of 100 mothers, 50 of whom were control group and the other 50 were case group, were sampled randomly. The data were collected via the "Family and Child Introductory Information Form" and the State-Trait Anxiety Inventory (STAI) which was developed by Spielberger et al.(1966) and translated and adapted into Turkish by Oner and Lecompte (1983). The data were evaluated via the IBM SPSS 13.00 statistical packaged software. The Analysis of Variance, Chi-Square, Student's t-test and Posthoc Turkey HSD were used to carry out analyses.Results:The groups' average STAI scores were compared before the surgery. The average SAI score of the control group before the surgery was $46.34 \pm 4.20$, and that of the case group was $41.72 \pm 4.14$. Therefore, there was a significant difference between the two groups $(p<0.05)$. When the average TAl scores before the surgery were compared, it was found that the average TAl score of the control group was $43.44 \pm 4.14$ and that of the case group was $41.98 \pm 4.34$. Therefore, there was no difference between the two groups $(p>0.05)$.
\end{abstract}

* ADDRESS FOR CORRESPONDENCE: Aysun Yılmaz, Eskisehir School of Health, Eskisehir Osmangazi University, Eskisehir, Turkey.E-mail address: aysuntureyilmaz@gmail.com 
The groups' average STAI scores were compared after the surgery. The average SAI score of the control group after the surgery was $42.08 \pm 5.60$, and that of the case group was $40.10 \pm 4.16$. Therefore, there was no difference between the two groups ( $p>0.05$ ). When the average TAI scores before the surgery were compared, it was found that the average TAl score of the control group was $42.32 \pm 4.12$ and that of the case group was $41.20 \pm 5.06$. Therefore, there was no difference between the two groups ( $p>0.05$ ).Conclusion and Recommendations: It was found that the anxiety levels of the mothers of children who visited the hospital to undergo an ambulatory day surgery was high; however, it was also found that the informing made before the surgery had a positive effect on decreasing the anxiety. Therefore, it should not be forgotten that the nursing care and informing done in accordance with ethical principles have a major contribution to nurses' professionalization and self-realization.

Key words:Anxiety, day surgery, children, mothers

\section{Introduction}

The most important factor in individuals being able to carry on their lives happily is their health. Being ill and hospitalised affects the lives of children and their families in many respects, and raises fears and anxieties. Situations where a surgical intervention is required for the healing of an illness particularly lead to psychological issues appearing in children and their families. The most observed reaction in families who learn that their children will be undergoing surgery is the feeling of guilt and anxiety, and the most important cause of anxiety prior to the surgery is the fear of the unknown. The other causes of anxiety for the family are lack of sufficient knowledge concerning the treatment, being in an unfamiliar environment, the fear of anaesthesia and the fear of losing their child $[1,2,3,4]$.

Day surgery is defined as the interventions for a patient, whose suitability for surgery has been determined in advance, being taken into surgery in the planned manner and who is then able to be discharged from hospital in the same day as the surgery [5]. Day surgery is a new surgical application for which the number and types of students are increasing. Day surgery is defined as being an approach which takes the surgical intervention implemented on hospital in-patients as its basis, but does not require a stay in hospital and foresees that the patient will be discharged on the same day [1, 2]. With this surgery, the patient returns to his / her normal life and family surroundings earlier and patient satisfaction increases $[6,7]$. One of the most significant differences between patients who are admitted for day surgery and in patients is that for one day patients, there is a requirement for the patient - nurse relationship to be conducted within a very limited period of time. The patient may not receive pre-operative training [3]. Therefore, it is necessary for the training of the patient to be started and continued with a multi-disciplinary approach, immediately after the decision has been made for the intervention.

Anxiety is a feeling of fear which is accompanied by various physical feelings and which is mostly ambiguous [8]. Anxiety is a normal, instinctive fear which appears in connection with a threat or the lack of an object. While small levels of anxiety increases spontaneous attention levels, courage and enterprise, as the levels of anxiety rise, the perception, understanding and decision making skills of the individual begin to fall [9].

Surgical interventions may increase anxieties in patients and their families for several reasons. The most important anxiety is fear of the unknown. The anxiety experienced by families may prevent them from correctly understanding explanations concerning their child, interpreting the situation in a realistic manner, making appropriate decisions, participating in the care for their child and using appropriate methods to deal with the situation $[1,2,3,4,10]$.

The family needs to be informed in order that the anxiety experienced by families can be reduced. The provision of information is a strategy which will reduce the fear and anxiety created by the lack of 
knowledge. Being informed ensures that the situation can be controlled and opens the door to the implementation of strategies to deal with the problem in a focused manner [1, 2].

Nurses need to prepare an atmosphere which is suitable for reducing the anxiety suffered by mothers due to their children being admitted to hospital and the surgical interventions, and where they are able to express themselves in order to be able to protect their own psychological and physiological balance. One of the fundamental duties of a surgical nurse is to be aware of the feelings, experience and expectations of the child and his / her family prior to the surgery, and help mothers deal with anxiety $[1,2,11]$.

This study has been planned as an illustrative study, with the aim of measuring the impact of informing mothers in connection with the day surgery directed at their children, on their levels of anxiety.

\section{Material and Methods}

The study is an interventionstudy, which was conducted between November 2005 - May 2006, with 100 mothers who agreed to take part in the study, at the Department of Otolaryngology and the Department of Pediatric Surgery of the Faculty of Medicine at Eskisehir Osmangazi University, and the Department of Pediatric Surgery at the Afyon Kocatepe University Hospital. Study group consisted of 100 mothers with 50 selected for the control group and 50 for the case group, by the random sampling method. A 'Family and Child Distinguishing Information Form', prepared by making use of the literature which was appropriate for the subject of the study, and Trait-State Anxiety Inventory, which was created by Spielberger et al (1966) [12] and adapted to Turkish by Oner and Lecompte (1983) [13] were used for the data.

The scale determines the levels of by case and continuous anxiety. The inventory consists of two separate scales of 20 items each.State Anxiety Inventory,determines how individuals feel at a specific point in time and under specific conditions. Trait Anxiety Inventory, determines how individuals feel independently of the situation and conditions they find themselves in.

The scales contain direct and reversed statements. When scoring reverse statements which voice positive feelings, those with a weighted value of 1 are converted to 4 and those with a weighted value of 4 are converted to 1 . Responses with a value of 4 in direct statements which express negative feelings indicate a high degree of anxiety. The total score obtained in both of the two scales ranges between20-80. Higher scores indicate a higher level of anxiety and lower scores indicate a lower level of anxiety [13].

Data collection tools have been applied by the researcher following face to face interviews. The children and families who arrived on the surgery days of the clinics were interviewed, and mothers who complied with the study criteria and who agreed to take part in the study were given two forms prior to surgery and the By Case - Continuous anxiety form again following surgery. Further, the mothers of the patients in the case group were given information about the operation by the researcher, prior to the operation, the department was introduced, a brochure prepared in advance presented, and opportunities were provided for the mothers to ask questions.

The SPSS 13.00 package programme was used in the analysis of the data. The chi-square test, significance test for the difference between two means ( $t$ test), ANOVA (variance analysis) and the Posthoc tukey HSD test (in the advanced assessment) were used during the statistical evaluation.

\section{Findings}

When the distribution of the genders of the children who took part in the study group was considered, it was seen that $40 \%$ of the control group was female and $60 \%$ was male, and that $34 \%$ of the case group was female and $66 \%$ was male. When the age distribution of the children was 
considered, it was seen that $50 \%$ of the control group and $38 \%$ of the case group were in the group of children aged 7 and above. When the matter of which number child the patient was in his /her family, it was seen that $58 \%$ of the control group and $38 \%$ of the case group were the first children in their families (Table 1).

Table1. The Distribution of Children According to their Distinguishing Characteristic

\begin{tabular}{|c|c|c|c|c|c|c|}
\hline \multirow[t]{3}{*}{ Characteristics } & \multirow{2}{*}{\multicolumn{2}{|c|}{$\begin{array}{l}\text { Control Group } \\
n=50\end{array}$}} & \multicolumn{2}{|c|}{ Case Group } & \multirow{3}{*}{$x^{2}$} & \multirow{3}{*}{$\mathrm{p}$} \\
\hline & & & $\mathrm{n}=50$ & & & \\
\hline & $\mathrm{n}$ & $\%$ & $\mathrm{n}$ & $\%$ & & \\
\hline \multicolumn{7}{|l|}{ Gender } \\
\hline Female & 20 & 40 & 17 & 34 & 0,172 & 0,679 \\
\hline Male & 30 & 60 & 33 & 66 & & $p>0.05$ \\
\hline \multicolumn{7}{|l|}{ Age } \\
\hline $0-2$ & 29 & 18 & 22 & 44 & 8,230 & 0.016 \\
\hline $3-6$ & 17 & 32 & 9 & 18 & & $p>0.05$ \\
\hline 7 and over & 4 & 50 & 19 & 38 & & \\
\hline \multicolumn{7}{|l|}{ Type of Surgery } \\
\hline Inguinal Scrotal P & 16 & 32 & 30 & 60 & & 0,068 \\
\hline Tonsil-Adenoid & 34 & 68 & 20 & 40 & 3,325 & $p>0.05$ \\
\hline \multicolumn{7}{|c|}{ Which number child of family } \\
\hline \multicolumn{7}{|c|}{1} \\
\hline \multirow[t]{2}{*}{2} & 29 & 58 & 19 & 38 & 4,006 & 0,045 \\
\hline & 31 & 42 & 31 & 62 & & $p<0.05$ \\
\hline \multicolumn{7}{|l|}{ Hospital experience } \\
\hline No & 26 & 52 & 16 & 32 & 3,325 & 0,068 \\
\hline Yes & 24 & 48 & 34 & 68 & & $p>0.05$ \\
\hline
\end{tabular}

When the age distribution of the mothers was examined (Table 2), it was seen that $82 \%$ of the control group and $68 \%$ of the case group were in the age group of mothers at the age of 30 and above. All of the mothers who took part in the study were literate. When the employment status of the mothers who participated in the study was examined, it was seen that $48 \%$ of the control group and $50 \%$ of the case group were in employment (Table 2 ).

Table 2. The Distribution of Mothers According to their Distinguishing Characteristics

\begin{tabular}{|c|c|c|c|c|c|c|}
\hline \multirow[t]{3}{*}{ Characteristics } & \multirow{2}{*}{\multicolumn{2}{|c|}{$\begin{array}{l}\text { Control Group } \\
n=50\end{array}$}} & \multicolumn{4}{|c|}{ Case Group } \\
\hline & & & \multicolumn{2}{|c|}{$n=50$} & \multirow[t]{2}{*}{$x^{2}$} & \multirow[t]{2}{*}{$p$} \\
\hline & $\mathrm{n}$ & $\%$ & $\mathrm{n}$ & $\%$ & & \\
\hline \multicolumn{7}{|l|}{ Age } \\
\hline $18-29$ & 9 & 18 & 16 & 32 & 1,920 & 0,166 \\
\hline 30 and over & 41 & 82 & 34 & 68 & & $p>0.05$ \\
\hline \multicolumn{7}{|l|}{ Education } \\
\hline Primary School & 18 & 36 & 17 & 34 & & 0,674 \\
\hline High School & 15 & 30 & 19 & 38 & 0,789 & $p>0.05$ \\
\hline University & 17 & 34 & 14 & 28 & & \\
\hline \multicolumn{7}{|l|}{ Work status } \\
\hline Employed & 24 & 48 & 25 & 50 & 0,048 & 0,976 \\
\hline Housewife & 26 & 52 & 25 & 50 & & $p>0.05$ \\
\hline
\end{tabular}

When the hospital experience of the families was examined (Table 3), it was seen that $76 \%$ of the control group and $56 \%$ of the case group had previous hospital experience.

Table 3. The Distribution of Families According to their Distinguishing Characteristics 
Yılmaz, A. \&Korkmaz, M.(2016). The effect of informing mothers on level of anxiety in day surgery of children, Global Journal on Advances in Pure \& Applied Sciences. [Online]. 07, pp 48-56. Available from: $\underline{\text { www.propaas.eu }}$

\begin{tabular}{|c|c|c|c|c|c|c|}
\hline \multirow[t]{2}{*}{ Characteristics } & \multicolumn{2}{|c|}{$\begin{array}{l}\text { Control Group } \\
n=50\end{array}$} & \multicolumn{2}{|c|}{$\begin{array}{l}\text { Case Group } \\
n=50\end{array}$} & \multirow[t]{2}{*}{$x^{2}$} & \multirow[t]{2}{*}{$\mathrm{p}$} \\
\hline & $\mathrm{n}$ & $\%$ & $\mathrm{n}$ & $\%$ & & \\
\hline \multicolumn{7}{|l|}{$\begin{array}{l}\text { No. of children in } \\
\text { family }\end{array}$} \\
\hline 1 & 16 & 32 & 15 & 30 & & 0,425 \\
\hline 2 & 24 & 48 & 29 & 58 & 2,790 & $p>0.05$ \\
\hline 3 or more & 10 & 20 & 6 & 12 & & \\
\hline \multicolumn{6}{|l|}{ Family Income } & \\
\hline Less than 1500 & 31 & 62 & 33 & 66 & 0,043 & 0,835 \\
\hline $\begin{array}{l}1500 \text { or more } \\
\text { Hospital } \\
\text { Experience }\end{array}$ & 19 & 38 & 17 & 34 & & $p>0.05$ \\
\hline No & 38 & 76 & 28 & 56 & 3,610 & 0.057 \\
\hline Yes & 12 & 24 & 22 & 44 & & $p>0.05$ \\
\hline
\end{tabular}

The pre-surgery by-case anxiety score means (DAP) and continuous anxiety score means (SAP) were compared. The pre-surgery by case anxiety score mean of the control group was determined as 46.34 \pm 4.20 , while that of the case group was determined as $41.72 \pm 4.14$, and the difference between the two groups was found to be significant $(p<0.05)$. The pre-surgery continuous anxiety score mean of the control group was determined as $43.44 \pm 4.14$, while that of the case group was determined as $41.98 \pm 4.34$, and the difference between the two groups was found to be insignificant $(p>0.05)$ (Table 4).

Table 4. The Comparison of the by Case - Continuous Anxiety Mean Scores of Mothers Prior to Surgery $(\mathrm{N}=100)$

\begin{tabular}{lll}
\hline & Prior to Surgery & Prior to Surgery \\
& DAP & SAP \\
Groups & $\mathrm{X} \pm \mathrm{SD}$ & $\mathrm{X} \pm \mathrm{SD}$ \\
\hline Control & $46.34 \pm 4.20$ & $43.44 \pm 4.14$ \\
Case & $41.72 \pm 4.14$ & $41.98 \pm 4.34$ \\
$\mathrm{t}$ & 5.531 & 1.721 \\
$\mathrm{p}$ & 0.00 & 0.088 \\
& $\mathrm{p}<0.05$ & $\mathrm{p}>0.05$ \\
\hline
\end{tabular}

The post-surgery by-case anxiety score means (DAP) and continuous anxiety score means (SAP) were compared. The post-surgery by case anxiety score mean of the control group was determined as $42.08 \pm 5.60$, while that of the case group was determined as $40.10 \pm 4.16$, and the difference between the two groups was found to be insignificant $(p>0.05)$. The post-surgery continuous anxiety score mean of the control group was determined as $42.32 \pm 4.12$, while that of the case group was determined as $41.20 \pm 5.06$, and the difference between the two groups was found to be insignificant ( $>0.05$ ) (Table 5).

Table 5. The Comparison of the by Case - Continuous Anxiety Mean Scores of Mothers Following Surgery $(\mathrm{N}=100)$

After Surgery After Surgery




\begin{tabular}{lll}
\hline & DAP & SAP \\
Groups & $\mathrm{X} \pm \mathrm{SD}$ & $\mathrm{X} \pm \mathrm{SD}$ \\
\hline Control & $42.08 \pm 5.60$ & $42.32 \pm 4.12$ \\
Case & $40.10 \pm 4.16$ & $41.20 \pm 5.06$ \\
$\mathrm{t}$ & 2.005 & 1.212 \\
$\mathrm{p}$ & 0.048 & 0.229 \\
& $\mathrm{p}>0.05$ & $\mathrm{p}>0.05$ \\
\hline
\end{tabular}

\section{Discussion}

When children are admitted to hospital mothers suffer anxiety for reasons such as a fear of the unknown, a fear of what will happen to the child, fear of loss or damage to their physical functions and body image, fear of death, despair, anger, fears concerning the recovery of the child, the unfamiliarity of the hospital environment, and guilt due to the illness of the child $[15,16]$.

As can be seen in Table 4, the by case anxiety scores and continuous anxiety scores of the groups prior to surgery have been compared. The pre-surgery by case anxiety score mean of the control group was determined as $46.34 \pm 4.20$, while that of the case group was determined as $41.72 \pm 4.14$, and the difference between the two groups was found to be significant $(p<0.05)$. The pre-surgery continuous anxiety score mean of the control group was determined as $43.44 \pm 4.14$, while that of the case group was determined as $41.98 \pm 4.34$, and the difference between the two groups was found to be insignificant $(p>0.05)$.

The studies which have been carried out show that patients are not sufficiently informed prior to the intervention and that they feel the need for information $[12,16,17,18,19,20,21]$. In the study by Turan and Bolısık (2003) where they examined the effects of the discharge training given to mothers with premature babies, on the mother and the baby, they found a statistically significant difference in favour of the case group in the test carried out on the mothers in the case group and control group following the training. They arrived at the conclusion that training at specific intervals during the time the baby was in the clinic would be more effective [22]. Ozmen (1992) determined that patients within hospitals had a high expectation for clearer information from nurses [17]. In another study, 90,8\% of the relatives of patients have requested that a written source, in a language they are able to understand, be provided [19].

When Donmez (1998) examined the anxiety levels of patients admitted to the surgical clinics of hospitals in order to have surgery and the influence of the nursing approach in eliminating this anxiety, he determined that the anxiety levels of the patients in the control group were higher than those in the case group. He argued that the reason for this difference was the nursing approach provided to the patients in the case group on their admission to hospital [18]. Chan (2002) carried out a study to determine the impact of training and the routine provision of information on the fears of parents who were to undergo day surgery, and determined that the fear of parents who did receive fell significantly when compared with the other group [23]. Senses (1997) has determined that the anxiety levels of mothers who were diagnosed as requiring abdominal surgery, fell on the morning of the surgery, following training [14]. In his study, Ozcengiz found that while the by case anxiety scores of parents who had received routine polyclinic information and detailed medical information did not change, the by case anxiety scores of parents who were given detailed medical information as well as a sharing of their feelings, had fallen by a significant level [24]. Aksit and Cimete (2001) studied the effect of the nursing care given to mothers during the admission of their children to the children's intensive care unit, on the anxiety levels of the mothers, and reached the conclusion that the supporting and anxiety reducing nursing approach applied to the mothers in the trial group had reduced the anxiety levels of the mothers [25]. In the study carried out by Algier et al (1991) it was 
determined that the anxiety levels of families who were not given information on the status of their child was higher [26]. In his study, Dolgun (2003) reached the conclusion that the book on pre-surgery preparations and post-surgery care for children who had had day surgery, had been evaluated positively by the families [4]. In the study carried out by Ozen (2005) he found that the anxiety levels of patients arriving at hospitals was high, but that the nursing approach which was implemented and the training provided was effective in terms of reducing anxiety. As patients do not have prior information concerning the intervention, in general they experience a fear and anxiety of everything [27]. Suhonen and Kilpi (2006) have scanned the literature and reached the conclusion that patient training in the period prior to surgery covers five important dimensions providing information on the illness, the manner and outcomes of the surgery / intervention, anaesthesia and its complications, hospital procedures and the psychosocial assessment of the patient [28]. In his study, Guven (2009) has stated that $69 \%$ of the patients who had day surgery (and who participated in the study) had had fears concerning the surgery [20]. In his study, Dolgun (2003), reached the conclusion that providing a book on pre-surgery preparations and post-surgery care for children who had had day surgery, had been evaluated positively by the families whose children were to have day surgery [4]. This result is parallel to our findings. Other studies on this matter also support the conclusion that anxiety may arise due to a lack of knowledge $[18,29,30]$.

These results are parallel to the findings of our study. It is known that there is a significant relationship between continuous and by-case anxiety scores, and that individuals with a high continuous anxiety score also have a high by-case anxiety score [4]. In our study, the by-case anxiety levels of the case group, who had been given information, were found to be lower than those of the control group. We are of the opinion that the provision of information prior to the surgical intervention made a contribution to this positive outcome.

As can be seen in Table 5, the post-surgery by-case anxiety score means and continuous anxiety score means were compared. The post-surgery by case anxiety score mean of the control group was determined as $42.08 \pm 5.60$, while that of the case group was determined as $40.10 \pm 4.16$, and the difference between the two groups was found to be insignificant $(p>0.05)$. The post-surgery continuous anxiety score mean of the control group was determined as $42.32 \pm 4.12$, while that of the case group was determined as $41.20 \pm 5.06$, and the difference between the two groups was found to be insignificant $(p>0.05)$. This can be explained by the fact that the surgical intervention has been completed and that the mothers become more at ease.

\section{Results and Suggestions}

The admission of children into hospital increases the anxiety levels of their mothers. This anxiety in the mothers is created as a consequence of a lack of knowledge, the discomfort caused by being in an unfamiliar environment and being far from home, the fear of anaesthesia, the fear of losing their child, and the fear of a change in the body image of their child. Importance needs to be placed on informing the family and the child at every stage of the treatment and on introducing the hospital environment in order to reduce this anxiety to the lowest possible levels, and it should not be forgotten that a fall in the anxiety levels of the mother will lead to a fall in the anxiety levels of the child as well.

Families should be given information by way of brochures on the illness of the child, while nurses need to be made aware that family training is a responsibility of professional nursing, and on the job training programmes should be prepared for nurses on the subjects of anxiety and training.

\section{References}

[1] Johnson J.H., (1996).Ambulatory surgery, JC Rathrock (Ed) Perioperative Nursing Care Planning, Mosby St Louis, 467-484

[2] Litwack K., (1995).Ambulatory surgery. Post-Anesthesia Care Nursing, Mosby St Louis, 352-374 
Yilmaz, A. \&Korkmaz, M.(2016). The effect of informing mothers on level of anxiety in day surgery of children, Global Journal on Advances in Pure \& Applied Sciences. [Online]. 07, pp 48-56. Available from: www.propaas.eu

[3] Yavuz M. (1998).Gunubirlik Cerrahi Hastalarin Bakını Icin Hemsire Bakim Formu Gelistirilmesi ve Formun Kalite Guvenliginin Izlemi, Ege Universitesi Saglık Bilimleri Enstitusu Doktora Tezi, Izmir

[4] Dolgun E. (2003).Gunubirlik Cerrahide Cocuk Hastaların Hemsirelik Bakimi Icin Yeniden Yapilanma, Ege Universitesi Saglik Bilimleri Enstitusu Yuksek Lisans Tezi, Izmir

[5] Bayraktar N., \& Cilingir D. (2006). Gunubirlik cerrahi sureci ve hemsirelik bakımı,Hemsirelik Yuksek Okulu Dergisi, 69-81.

[6] Malster M., \&Perry A., (1999).Day Surgery. A Nursing Apprococh Mosby St Louis, 286-288

[7] Boyacı M. (2003).Cocuk Cerrahisinde Gunubirlik Olgulara Yonelik Gelistirilen Hemsirelik Bakim Standartlarnin Aile Anksiyetisinin Azaltmaya Etkisi, Marmara Universitesi Saglik Bilimleri Enstitusu Yuksek Lisans Tezi, Istanbul.

[8] Modern Medicine (1993). Guncel Tip Aylik Klinik Tip Dergisi, Turgut Yayincilik, Istanbul, 1(10), 25-26

[9] Aktan S., \&Utku U., (1987). Turkiye Saglik ve Tedavi VakfiYeni Tip Dergisi Cilt, 4(5), 52-53.

[10] Malster, M., \&Perry, A., (2000). Day surgery. Surgial Nursing Advencing. Practice Churchii Livingstone, 161286

[11] Watson, D., S., \&Sangerino, C., A., (1995). Ambulatory surgery. Care of The Patient Surgery. Mosby St Louis, 1125-1144

[12] Spielberger, C., D. (1966). Theory and Research on Anxiety. In: CD Spielberger (Ed), Anxiety and Behavior, New York, 17-20.

[13] Oner, N., \& LeCompte, W. A. (1983). Durumluk-surekli kaygı envanteri el kitabi. Bogazici Universitesi.

[14] Senses, M. (1997).Cocuklarina Batin Ameliyati Endikasyonu Konulan Annelerin Egitiminin Anksiyete Uzerine Etkisi, Istanbul Universitesi Saglik Bilimleri Enstitusu Yuksek Lisans Tezi, Istanbul.

[15] Lancester, K.A. (1997). Patient teaching in Care of the pedratric patient in ambulatory surgery. Nursing Clinics of North America, 33(2), 417-427

[16] Alak, V. (1992).Hastaneye Ameliyat Olmak Uzere Gelen 7-14 YasGrubu Cocukların Korkuları ve Hemsirelik Uygulamaları, Ege Universitesi Saglık Bilimleri Enstitusu Doktora Tezi, İzmir.

[17] Ozmen D., (1992).Dokuz Eylul Universitesi Tıp Fakultesi Hastanesinde Yatan Hastaların Beklentilerinin Saptanması. 2. Ulusal Hemsirelik Kongresi Bildiri Kitabı, Ege Universitesi Basımevi, İzmir.

[18] Donmez Z., (1998). Cerrahi Kliniklerine Ameliyat Olmak Uzere Yatan Hastalarin Hastaneye Yatistaki Anksiyeteleri ve Anksiyeteyi Gidermede Hemsirelik Yaklasiminin Etkisinin Incelenmesi. Ege Universitesi Saglik Bilimleri Enstitusu Yuksek Lisans Tezi, İzmir.

[19] Aksit S., (1998). Cocugun Yogun Bakim Unitesine Kabulunde Annelere Uygulanan Hemsirelik Bakiminin Annelerin Anksiyete Duzeyine Etkisi.Istanbul Universitesi Saglik Bilimleri Enstitusu Yuksek Lisans Tezi, Istanbul.

[20] Guven, B. (2009). Gunubirlik Cerrahide Hasta ve Yakınlarının Ameliyat Sonrasına iliskin Endiselerinin Degerlendirilmesi, Marmara Universitesi, Saglık Bilimleri Enstitusu, Yuksek Lisans Tezi, İstanbul

[21] Gulturk, E. (2012).Gunubirlik Cerrahiye Basvuran Kadin-Dogum Hastalarinin Perioperatif Hemsirelik Bakim Gereksinimleri Ve Karsilanma Durumu, Akdeniz Universitesi Saglik Bilimleri Enstitusu Yuksek Lisans Tezi, Antalya

[22] Turan, M.T., \&Bolisik B., (2003) Premature Bebegi Olan Annelere Serviste Uygulanan Taburcu Egitiminin Etkinliginin Incelenmesi. C.U.Hemsirelik Yuksekokulu Dergisi, 7(1), 39-46

[23] Chan, C.S.M, \& Molassiotis M. (2002). The effects of an educational programme on the anxiety and satisfaction level of parents having parent present induction and visitation in a postanaesthesia care unit." Peadiatr Anaesth, 12, 131-9.

[24] Ozcengiz, D. (2006). Anesteziyle Ilgili Bilgilendirmede Kullanilan Farkli Yaklasimlarinin Cocuklari Gunubirlik Cerrahi Mudahale Geciren Ebeveynlerin Durumluk Kaygılarina Etkisi,Yayinlanmamis Yuksek Lisans Tezi, Cukurova Universitesi, Sosyal Bilimler Enstitusu, Adana.

[25] Aksit, S., \& Cimete, G. (2001) Cocugun Yogun Bakim Unitesine Kabulunde Annelere Uygulanan Hemsirelik Bakiminin Annelerin Anksiyete Duzeyine Etkisi. C.U. Hemsirelik Yuksekokulu Dergisi, 5(2), 25-35

[26] Algıer L., (1991).Hastanede Yatan Adolesanlarin KaygiDuzeylerinin Saptanması ve Kaygıya Neden Olacak Faktorlerin Belirlenmesi. Hacettepe Universitesi Saglık Bilimleri Enstitusu Doktora Tezi, Ankara. 
[27] Ozen A., (2005).Urodinamik Girisim Uygulanacak Hastalarin Islem Oncesi Bilgilendirilmesinin Anksiyete Duzeylerine Etkisi. Eskisehir Osmangazi Universitesi Saglik Bilimleri Enstitusu Yuksek Lisans Tezi, Eskisehir.

[28] Suhonen, R., \&Kilpi, H., L. (2006).Adult Surgical Patients and the Information Provided to them by Nurses: A Literature Riview. Patient Education and Counseling, 61, 5-15.

[29] Karayurt,O. (1998). Ameliyat Oncesi Uygulanan Farkli Egitim Programlarinin Hastalarin Agrive Anksiyrte Duzeylerine Etkisinin Incelenmesi. C.U. Hemsirelik Yuksekokulu Dergisi, 2(1), 22-26

[30] Aksit, S. (1998). Cocugun Yogun Bakim Unitesine Kabulunde Annelere Uygulanan Hemsirelik Bakiminin Annelerin Anksiyete Duzeyine Etkisi. Istanbul Universitesi Saglık Bilimleri Enstitusu Yuksek Lisans Tezi Istanbul. 